\title{
MENCIPTAKAN PERDAMAIAN MELALUI PENDIDIKAN PERDAMAIAN DI SEKOLAH
}

\author{
Taat Wulandari, M. Pd. ${ }^{*}$
}

\begin{abstract}
Abstrak
Suatu negara dengan keadaan masyarakat yang beragam akan sangat rentan untuk terjadinya sebuah konflik. Indonesia adalah suatu negara yang memiliki keadaan tersebut dihadapkan pada masalah yang tidak ringan. Dibutuhkan keterampilan mengatur keberagaman tersebut agar semua komponen masyarakat dapat hidup dengan aman, nyaman, tenteram, dan damai bagi kelangsungan kehidupan bermasyarakat, berbangsa, dan bernegara. Namun, bangsa Indonesia tercinta ini masih diselimuti oleh berbagai konflik yang muncul dalam masyarakat. Masyarakat perlu dibekali oleh berbagai pengetahuan tentang keadaan bangsanya sejak dini. Pendidikan merupakan perantara yang tepat untuk menumbuhkan bermacam sikap yang mendukung tercapainya perdamaian.
\end{abstract}

Kata Kunci: Konflik, Pendidikan, dan Perdamaian.

\section{A. Pendahuluan}

Sudah sedemikian parahkah situasi keterpurukkan bangsa tercinta ini? Atau sudah demikian tipisnya nilai-nilai moral dari sebagian anak bangsa generasi penerus bangsa? Dan masih segudang pertanyaan yang seringkali menghantui pikiran - pikiran mereka yang sedih melihat kenyataan yang terjadi di negara Indonesia dalam semua aspek kehidupan. Di berbagai media massa berita tentang pembunuhan, pencurian, korupsi sistemik di semua birokrasi, konflik antar masyarakat, perkelahian pelajar, penggusuran, konflik agama, dan sebagainya, sepertinya sudah menjadi konsumsi setiap orang. Bukan hal yang menggembirakan tentunya dan yang pasti harus dicari solusinya.

Krisis multidimensi sepertinya masih enggan hengkang dari Indonesia, tak terkecuali dalam bidang pendidikan. Pendidikan yang dipandang sebagai suatu proses memanusiakan manusia, dalam kenyataannya masih sebatas wacana saja. Terbukti ketika pendidikan hanya dijadikan sebagai alat politik oleh para penguasa, pendidikan hanya digunakan untuk mengejar strata ekonomi dan sosial yang tinggi. Bukti-bukti ini menunjukkan bahwa hakekat pendidikan jauh dari memanusiakan manusia. Fenomena tersebut

\footnotetext{
* Dosen pada Program Studi Pendidikan IPS FISE UNY.
} 
mengisyaratkan adanya krisis yang dialami dunia pendidikan kita dan mengingatkan agar dilakukan penanganan yang serius. Sudahkah pendidikan Indonesia berpijak pada landasan yang kuat? Sudahkah lembaga pendidikan yang ada berfungsi sebagaimana mestinya?

Sebetulnya, peran lembaga pendidikan sebagai agent of change sudah sangat tepat. Namun, sampai pada saat ini baru sebatas merubah dari yang tidak tahu menjadi tahu. Baru pada tataran koqnitifnya saja. Perubahan koqnitif tadi sayangnya belum diikuti dengan kecerdasan lain untuk mengimbanginya, yaitu kecerdasan emosi dan kecerdasan religius. Dua kapling itu yang belum diolah secara tepat. Jadi, jangan heran jika proses pendidikan hanya mencetak manusia-manusia pinter dan kadang dipakai untuk minteri orang lain. Polah tingkahnya justru tidak mencerminkan sebagai manusia yang cerdas. Akibatnya apa? Pendidikan sering dianggap gagal dalam membina siswanya cerdas intelektualnya, emosinya, dan religiusnya.

Ketika dalam suatu masyarakat marak terjadi konflik, marak perkelahian antar pelajar, pendidikan juga yang terkena imbasnya. Apa yang salah dalam sistem pendidikan di Indonesia? Sudah menjadi lagu lama mencari akar keterpurukkan sistem pendidikan kita. Sayangnya baru sebatas teori, belum sampai pada tataran aplikasinya. Pendidikan sendiri jarang sekali dijadikan isu sentral dalam setiap kampanye pemilihan. Mana ada calon pemimpin yang menjadikan pendidikan sebagai pogram utamanya. Hal ini mengindikasikan bahwa pendidikan dipandang tidak terlalu penting dalam kehidupan negara. Bandingkan dengan Amerika Serikat! Pendidikan selalu menjadi isu sentral dalam setiap kampanye calon presiden.

Ketika situasi masyarakat yang penuh dengan kekacauan, konflik, dan tidak ada perdamaian, pendidikan dipandang sebagai pihak yang ikut berdosa karena gagal mewujudkan warga negara yang baik. Sekolah idealnya menjadi sarana yang tepat dalam menanamkan nilai-nilai moral yang mendukung terciptanya perdamaian dalam masyarakat. Alasan ini sejalan dengan peran lembaga pendidikan sebagai institusi yang bertugas menumbuhkan dan memperdalam cinta pada tanah air, mempertebal semangat kebangsaan, dan rasa kesetiakawanan sosial.

Di Indonesia yang penduduknya sangat plural, baik ras, agama, bahasa, adat-istiadatnya, dsb, memang rentan sekali untuk terjadi konflik. Jika mencermati isi kurikulum, nampak bahwa kurikulum di Indonesia belum memperhatikan aspek keberagaman tersebut. Mungkin hal ini masih 
dibingungkan dengan pencarian format yang tepat seperti apa jika pendidikan untuk menciptakan perdamaian diberikan di sekolah-sekolah atau lembaga pendidikan lainnya. Sehingga jika berbicara tentang sistem pendidikan maka yang harus diubah adalah semua yang terkait dalam sistem itu, kurikulumnya, gurunya, muridnya, sarana dan prasarananya, dsb. Kerukunan, moral, perdamaian, dan konflik merupakan hal yang saling berkaitan. Nampaknya memang pendidikan kita belum berkontribusi nyata dalam upaya mewujudkan kehidupan yang rukun dan damai. Makalah ini berusaha untuk menyajikan peran sekolah dalam menciptakan perdamaian.

\section{B. Konflik}

Konflik merupakan antitesisnya Perdamaian. Antara konflik dan perdamaian adalah dua hal yang sangat berlawanan. Konflik bisa terjadi dimana saja, kapan saja, oleh siapa saja, dan dalam situasi apa saja. Di dalam buku Peace Education, Amy Ohlendorf (Zamroni, 2008: 12), memberikan definisi tentang konflik yaitu hasil dari adanya perbedaan pandangan, penerimaan, dan nilai-nilai seseorang ataupun sekelompok orang. Dalam masyarakat yang homogen pun konflik dapat saja terjadi. Apalagi dalam sebuah entitas politik yang heterogen baik suku bangsa, agama, adat-istiadat, dan sebagainya, sudah lazim jika konfik sering muncul.

Setiap orang pun tidak luput mengalami konflik. Gary T. Furlong, dalam bukunya The Conflict Resolution Toolbox, mengatakan: kita semua dihadapkan pada situasi konflik di dalam banyak aspek kehidupan kita, apakah di kehidupan pribadi setiap orang, di dalam lingkungan kerja, atau dengan seseorang yang baru kita kenal sekalipun. Konflik yang ada bisa saja mengarah ke konflik yang sifatnya massal dengan menggunakan kekerasan fisik. Perlu langkah yang tepat bagi seseorang yang dihadapkan pada situasi konflik, agar konflik tidak melebar dan menjurus ke arah pertumpahan darah. Orang sekarang apalagi yang masih muda-muda sangat gampang sekali tersulut api kemarahan oleh masalah kecil/sepele yang seharusnya tidak sampai ke arah terjadinya konflik secara terbuka.

Menurut Amy Ohlendorf dalam buku Peace Education, Volume II, (Zamroni, 2008: 14), dijelaskan tentang pengertian konflik yaitu suatu situasi persaingan yang didalamnya orang-orang sadar akan adanya ketidaksesuaian posisi potensial di masa depan dan masing-masing orang berniat untuk menguasai posisi yang dirasa tidak sesuai untuk yang lainnya. Konflik 
diibaratkan sebagai siklus: " sama dengan proses sosial, ada sebabnya, ada prosesnya, yang mempunyai akibat atau dampaknya.

\section{Perdamaian}

Perdamaian bisa diartikan bermacam-macam. Perdamaian adalah sebuah istilah/kata untuk menyebut suatu kondisi adanya harmoni, kemanan (tidak terjadi perang), serasi, dan adanya saling pengertian. Perdamaian juga bisa diartikan suasana yang tenang dan tidak adanya kekerasan. (Zamroni: materi kuliah pendidikan perdamaian PPs UNY) Dalam situasi penuh perdamaian maka akan tercipta kerukungan antar anggota masyarakat. Perdamaian sebetulnya bisa dikembangkan dengan mengendalikan emosi setiap orang. Karena kekurangmampuan mengatur emosi itulah yang gampang terbakar jika tersulut api sedikit saja.

Untuk mewujudkan kondisi masyarakat dari tingkat paling kecil sampai ke tingkat yang besar, negara misalnya, dalam diri setiap orang perlu dikembangkan sikap tenggangrasa dengan orang lain, saling pengertian, empati, kerjasama, dan respect terhadap orang lain. Perlu sekali disadari bahwa masyarakat kita adalah masyarakat yang plural dan multikultural. Dan dalam kondisi masyarakat seperti ini yang vital adalah pemahaman bahwa satu orang dengan yang lainnya berbeda dalam berbagai hal. Oleh karena itu memaksakan budaya seseorang kepada orang lain tidak dibenarkan.

\section{Pendidikan}

Banyak sekali pengertian tentang pendidikan. Salah satunya adalah bahwa pendidikan adalah usaha sadar yang bertujuan dan mendewasakan anak yang mecakup kedewasaan intelektual, sosial, dan moral. (Saidiharjo: 2004: 10). Pendidikan ini memang memegang kunci yang membuka pintu gerbang seseorang, sebuah masyarakat bahkan sebuah bangsa ke arah jalan panjang terjadinya kemajuan. Hal ini logis saja karena diharapkan melalui proses pendidikan akan dihasilkan generasi yang berwawasan luas, cerdas, dan dengan kecerdasannya itu mereka akan membangun bangsanya. Sayangnya, generasi kita (sebut saja para pelajar) masih ada gejala yang menunjukkan kelemahan dalam kecerdasan emosinya, empatinya, respect, multikulturalisme. Akibatnya kehidupan yang rukun dan damai sepertinya masih separuh jalan. Apalagi jika kita menoleh ke daerah-daerah penuh konflik, pelakunya dari anak-anak sampai orangtua. Ini menunjukkan pendidikan belum berhasil. 
Pendidikan terjadi melalui interaksi insani dimulai dari lingkungan keluarga, kemudian dilanjutkan dan ditempa dalam lingkungan sekolah, dan diperkaya dalam lingkungan masyarakat. Hasil pendidikan inilah yang digunakan dalam membangun kehidupan pribadi, agama, keluarga, masyarakat, bangsa, dan negaranya.

\section{E. Konseptualisasi}

Jika pendidikan adalah suatu proses untuk mendewasakan intelektual, sosial, dan moral, maka sudah seharusnya lembaga pendidikan dapat berfungsi dengan baik guna memberi peran serta mewujudkan kehidupan yang rukun damai. Singkatnya pendidikan harus mampu menghasilkan generasi yang sadar akan kondisi masyarakat yang beranekaragam. Mampu menghindari terjadinya konflik sehingga impian akan terciptanya suasana penuh damai bukan menjadi hal yang utopis.

Oleh karena itu, hal yang terpenting adalah menjadikan sekolah sebagai wahana untuk mengasah ketajaman dan kepekaan akan lingkungan sosial yang berbeda-beda. Melihat kenyataan bahwa konflik adalah suatu kenyataan hidup, tidak bisa dihindarkan, maka bagaimana pendidikan di sekolah-sekolah mengajarkan kepada siswanya jika dihadapkan pada suatu konflik.

Aspek - aspek yang terkait dalam pendidikan perlu dikembangkan untuk mendukung tujuan bahwa sekolah harus mencetak generasi yang proaktif terhadap usaha-usaha menciptakan perdamaian. Karena pendidikan adalah suatu proses yang terus menerus, pendidikan perdamaian ini tentunya juga harus diberikan pada setiap level sekolah dari yang paling dasar sampai level yang tertinggi. Pembelajaran tentang perdamaian tentu saja harus disesuaikan dengan perkembangan usia peserta didik. Materinya juga harus melihat perkembangan usia tadi. Sasaran siswa setiap level itulah yag menjadi sasarannya. Setiap aspek pendidikan yang meliputi siswa, guru, kurikulum, pemerintah, dan masyarakat harus mendukung terwujudnya perdamaian.

\section{F. Pendidikan Perdamaian Di Sekolah}

Untuk mewujudkan perdamaian melalui pendidikan maka perlu diberikan pendidikan perdamaian disetiap level pendidikan. Manusia secara alamiah berkembang melalui proses belajar. Tahap pertama seorang anak belajar adalah dari apa yang ada di sekitarnya. Dalam hal ini keluarga adalah media belajar pertama. Kemudian tahap berikutnya diperoleh dari 
sekolah/pendidikan formal. Sehingga pendidikan untuk mendukung perdamaian dapat diberikan kepada anak-anak maupun orang dewasa baik secara formal dan pendidikan informal.

Mengapa sekolah sangat mendukung untuk terciptanya perdamaian? Hal ini melihat peranan pendidikan formak/ sekolah yang berperan melanjutkan pengetahuan, ketrampilan, dan sikap-sikap yang telah diperoleh di keluarga. Sekolah adalah gambaran sebuah masyarakat kecil. Di dalamnya terdapat individu-ndividu dengan berbagai macam karakter dan kulturnya. Di tempat inilah sangat relevan dan pas untuk mengenalkan serta melatih berbagai nilai yang mendukung perdamaian. Selan itu sistem pendidikan adalah sarana untuk menciptakan kemajuan dalam masyarakat. Setiap masyarakat membutuhkan lembaga kependidikan untuk mendidik "generasi-generasi baru”. Dalam konteks ini sekolah adalah sebuah lembaga yang mempersiapkan individu-individu bagi kehidupan dan memungkinkan untuk mengembangkan diri dan memperluas wawasannya.

Anak-anak yang menjadi generasi penerus bangsa merupakan modal bangsa yang harus betul-betul digarap kecerdasan intelektual, spiritual, dan emosionalnya. Mengingat dipundak merekalah nasib bangsanya ditentukan. Di berbagai mass media sering kita saksikan fenomena pelajar merusak kampus, perkelahian antar pelajar, berita tentang kenakalan-kenakalan remaja, permusuhan, dan berbagai konflik lain. Sehingga pendidikan perdamaian di sekolah-sekolah bertujuan untuk mengatasi ketidakseimbangan tersebut. Tujuannya tidak lain adalah untuk membantu mewujudkan situasi kehidupan yang rukun, aman, tenang, dan tanpa konflik. Memberikan sebuah wacana kehidupan yang lain bahwa masyarakat kita mampu untuk hidup harmonis dengan sesama manusia, dan dengan seisi bumi ini. Harapan-harapan tersebut sebetulnya masih ada. Tinggal bagaimana kita menggarapnya. Nah, sekolah sebagai wadah setiap anak untuk memperoleh pengetahuan dan ketrampilanketrampilan lain bisa memberikan kontribusinya.

Banyak sikap-sikap yang baik untuk dikembangkan dan untuk membangun sebuah masyarakat dan dunia yang baik. Sikap tersebut antara lain: menghormati diri sendiri, toleransi, empati, keadilan, kejujuran, tidak saling mencurigai, persahabatan, kerjasama, saling pengertian, dan keadilan/pemerataan. Pada akhirnya setiap orang harus memberikan sumbangannya untuk perdamaian dunia. Masalah yang kelihatannya dominan di masyarakat kita adalah terjadinya konflik yang berpangkal pada tidak 


\section{Menciptakan Perdamaian Melalui Pendidikan Perdamaian di Sekolah}

adanya saling pengertian dan sifat mudah tersinggung. Kadang konflik seperti ini juga mengarah ke konflik fisik. Di sini orang sepertinya tidak menghargai diri sendiri. Begitu mudah nyawa dijadikan taruhannya hanya karena tidak bisa mengendalikan emosi. Oleh karena itu, pendidikan perdamaian di sekolahsekolah menurut saya lebih difokuskan pada penanaman nilai-nilai di atas.

Selain sikap-sikap di atas, dalam pendidikan perdamaian juga harus mampu mengembangkan ketrampilan-ketrampilan, seperti: mampu berkomunikasi, mendengarkan, memahami pandangan-pandangan yang berbeda, mampu bekerjasama, pemecahan masalah, berpikir kritis, pengambilan keputusan, pemecahan konflik, dan tanggungjawab sosial. Sepertinya ketrampilan tersebut sudah jauh dari anak-anak generasi penerus bangsa.

Selain untuk penanaman sikap atas nilai-nilai yang wajib dalam menciptakan perdamaian, menurut Harris (1996) seperti yang ditulis oleh Romo, Jaime J; Quezada, Reyes dalam Peace Education (Zamroni, 2008: 47), pendidikan perdamaian adalah suatu usaha pembelajaran yang memberikan kontribusi dan membentuk warganegara yang baik di dunia. Yang harus disajikan adalah alternatif-alternatif dengan mengajarkan sebab-sebab kekerasan dan menginformasikan kepada siswa pengetahuan tentang masalahmasalah pokok dalam pendidikan perdamaian, antara lain: menjaga, menciptakan, dan membangun perdamaian.

Pada tataran sekolah dasar dan lanjutan dapat mendukung ketiga issue tadi. Pada tahap menjaga perdamaian disemua jenjang sekolah harus mempunyai aturan keras yang berani mengeluarkan muridnya jika terlibat dalam suatu tindak kekerasan. Langkah ini bisa dengan memperkerjakan penjaga keamanan. Usaha menciptakan perdamaian bisa dilakukan dengan memasukkan programnya kedalam kurikulum sekolah dengan mengambil program-program untuk memproosikan strategi pembelajaran dalam pemecahan konflik, mediasi, manajemen konflik, kesadaran budaya, dan pendidikan inklusiv.

Program menciptakan perdamaian ini di sekolah diharapkan dapat membantu mengurangi pengalaman-pengalaman verbal, penyiksaan fisik, kekacauan, penyerangan, pengrusakan, perkelahian, penghinaan, dan luka-luka. Dan dapat memberikan perasaan memiliki di kalangan para murid, meningkatkan kepedulian sosial, dan membangun kemampuan mempertinggi kerjasama. Diharapkan program menciptakan perdamaian dapat memberikan 
kesempatan adanya dialog dan komunikasi positif serta membangun daya lentur anak-anak muda.. Membangun perdamaian bisa merupakan tahap yang sulit karena berkaitan dengan perubahan sikap individu yang mengarah ke kekerasan dan rasisme. Tujuannya adalah untuk memajukan dan mencari format perdamaian positif yang dapat memberimasukkan dalam hal kerjasama, kepercayaan, dan komunikasi terbuka sebagai sarana yang berhubungan dengan masyarakat global.

Untuk keperluan menjaga, menciptakan, dan membangun perdamaian yang harus disiapkan adalah hal-hal yang berkaitan dengan sumber daya manusia yang memiliki pengetahuan dan ketrampilan tentang memajukan pendidikan perdamaian di kelas. Masalah di lapangan untuk aspek guru salah satunya memang berkenaan dengan kesulitan guru mencari format yang tepat untuk mempromosikan dan menanamkan pendidikan perdamaian.

Pemerintah selama ini belum menjadikan pendidikan perdamaian sebagai materi yang wajib diajarkan disekolah-sekolah. Peran pemerintah sebetulnya penting dalam menciptakan perdamaian melalui lembaga pendidikan atau sekolah. Di dalam kurikulum sekolah dari tingkat dasar sampai lanjutan, selama ini belum memuat materi tentang pendidikan perdamaian. Pendidikan yang bertujuan meningkatkan keimanan dan ketaqwaan (imtaq) misalnya, masih dijadikan sebagai hidden curriculum. Alternatif-Alternatif Implementasi pendidikan perdamaian di sekolah antara lain:

\section{Alternatif pertama}

Fokus pendidikan untuk mendukung perdamaian melalui lembaga pendidikan (sekolah dan universitas) terutama untuk mengatasi masalahmasalah yang penting dan berkecenderungan ada di masyarakat. Jika berbicara tentang pendidikan perdamaian di sekolah maka terdapat tiga aspek yang menyusunnya, yaitu: apa materinya? dan bagaimana proses pembelajarannya?

Sebetulnya masih banyak pendidik yang masih belum mengerti apa itu pendidikan perdamaian. Seperti apa yang penulis alami ketika dalam suatu rapat pembentukan program pendidikan IPS, yang dalam rancangan mata kuliahnya terdapat mata kuliah pendidikan perdamaian. Banyak komentar yang muncul, seperti; apa itu pendidikan perdamaian? Terus materi yang mau diajarkan itu seperti apa? Yang mengajar terus lulusan jurusan apa? Serta beberapa pertanyaan lain yang perlu jawaban. 
Materi pendidikan perdamaian harus berhubungan dengan tujuan pendidikan perdamaian yang akan dicapai. Dalam suatu wilayah yang terus menerus terjadi konflik/peperangan antar kelompok warga, misalnya. Maka di lembaga pendidikan yang ada di wilayah tersebut paling mendesak adalah pendidikan untuk menghapus budaya perang dan kekerasan. Kasus lain seperti suatu tempat di mana banyak terjadi pelanggaran hak asasi manusia, maka sekolah harus mempromosikan pendidikan untuk menjunjung tinggi hak asasi manusia. Pecahnya konflik/perang dengan latar belakang karena masing-masing mempunyai kultur yang berbeda, maka materi untuk membangun solidaritas lintas kultur perlu diajarkan dalam pendidikan perdamaian. Tentunya materi tidak hanya apa yang paling dominan di tingkat lokal. Bisa saja materi lain juga ditanamkan agar pengetahuan murid luas dan dapat mengantisipasi konflik di luar alasan yang utama. Materi lain dapat berkaitan misalnya pendidikan untuk hidup adil dan penuh kasih, pendidikan untuk memelihara lingkungan, dan pendidikan untuk kedamaian pribadi.

Secara umum materi dalam pendidikan perdamaian adalah bagaimana menanamkan sikap-sikap untuk menjadi warga negara yang baik. Sikap yang dapat mengatasi ketidakseimbangan yang terjadi antara harapannya dan kenyataan (dengan melihat dan menganalisis gejala yang terjadi di masyarakat baik lokal maupun global). Di sini perlunya guru untuk selalu meningkatkan pengetahuan tentang isu-isu sosial. Materi pendidikan perdamaian diberikan dengan tujuan akhir yaitu untuk membangun budaya perdamaian dalam masyarakat. Yang perlu diingat adalah, materi-materi itu tidak harus diberikan dalam mata pelajaran tersendiri bahkan akan lebih baik jika semua materi itu masuk dalam semua mata pelajaran yang diberikan dalam kurikulum.

Dalam pendidikan perdamaian, sama dengan proses belajar untuk memahami pengetauan lain, perlu diciptakan suatu proses yang menyenangkan. Pembelajar dimungkinkan bisa belajar sesuai dengan apa yang diperlukan oleh dirinya dan diarahkan untuk membentuk pribadi yang damai. Proses belajar dapat dengan belajar secara menyeluruh. Disini yang diartikan menyeluruh adalah proses pembelajaran itu melibatkan pikiran, hati, dan semangat. jadi pembelajar benar-benar meresapi dan mengerti apa yang dia pelajari, bukan hanya untuk memperkaya pikiran maupun keilmuan dia akan tetapi juga memperkaya hatinya. Menyeluruh disini juga 
berarti melibatkan semua aspek dalam kehidupan dari tingkat individu sampai tingkat bangsa atau negara atau dunia. Melibatkan semua sektor dalam masyarakat. Dilaksanakan di semua tingkat pendidikan; dari tingkat dasar sampai tingkat tertinggi dan dalam bentuk pendidikan formal, nonformal, maupun informal. Selain itu juga menyeluruh dalam artian keterkaitan semua bidang ilmu.

Pendidikan perdamaian melalui proses belajar dengan berdialog. Dalam bentuk ini antara guru dengan murid dalam posisi yang sama dan saling belajar. Dialog sendiri juga melatih murid dan guru untuk saling menghormati karena di dalam dialog terdapat unsur "mendengarkan dengan baik” yang kemudian membuka wawasan murid dan guru untuk dapat menerima ide-ide baru. Selain itu melalui dialog maka akan terbangun suasana demokratis dan juga membuka kemungkinan semua pihak untuk berpartisipasi aktif dalam proses pembelajaran.

Pendidikan perdamaian juga dirancang untuk mendorong pemikiran kritis dari murid, yang nantinya diharapkan akan memunculkan komitmen dari murid untuk berperan serta dalam proses transformasi kehidupan ke arah yang lebih baik dan juga berperan dalam membangun budaya damai. Komitmen itu bisa saja pada tingkat personal tetapi juga bisa mencakup pada lingkungan yang lebih luas.

Pada akhirnya, pendidikan perdamaian ini akan menghasilkan budaya damai yang mungkin digali dari budaya lokal, dan bisa juga merupakan bentukan baru yang merupakan konsensus bersama. Di dalam hubungan ini, yang perlu diperhatikan adalah kedudukan guru dan murid adalah sama dan setara. Keduanya berfungsi sebagai sumber ilmu dan ketrampilan, tetapi keduanya juga berfungsi sebagai orang yang belajar. Guru lebih berfungsi sebagai fasilitator dalam proses pembelajaran ini.

Siapa yang mengajarkan materi pendidikan perdamaian? Menurut saya tergantung dari strategi pembelajarannya seperti apa. Sebetulnya siapa saja dapat menyampaikan materi ini. Dengan syarat memang harus mempunyai perhatian terhadap isu-isu sosial. Syarat ini harus dipenuhi apabila pendidikan perdamaian diberikan sebagai mata pelajaran tersendiri di sekolah. Jadi tidak dimasukkan ke dalam kurikulum mata pelajaran tertentu atau semua mata pelajaran harus memuat materi pendidikan perdamaian. Nah, jika materi pendidikan perdamaian dimasukkan dalam 
kurikulum semua mata pelajaran, maka mau tidak mau guru mata pelajaran yang bersangkutan memang harus mengajarkan materi tersebut.

\section{Alternatif kedua}

Pendidikan perdamaian diajarkan di sekolah-sekolah dapat diajarkan tersendiri dalam satu mata pelajaran atau bisa juga diberikan melalui mata pelajaran yang sudah ada. Dalam buku Mengelola Konflik ( , : 142) diberikan contoh tentang topik yang diajarkan pada mata pelajaran tertentu di sekolah seperti:

a. Pendidikan Agama, dapat memuat ajaran tentang perdamaian di setiap agama

b. Sejarah, dengan memberikan contoh-contoh tindakan anti-kekerasan dan pengembangan perdamaian

c. Geografi, mengajarkan tentang cara mengatasi prasangka dan memperlihatkan interaksi / hubunga antarmanusia

d. Sastra, misalnya dengan membaca dan menganalisis karya sastra tentang perdamaian. Pada mata pelajaran yang lain seperti:

e. Sosiologi, ajaran tentang perubahan sosial budaya dan faktor-faktor yang menimbulkan konflik serta cara pencegahannya

f. Pendidikan Kewarganegaraan, ajaran yang berkaitan dengan hukum, demokrasi, dan HAM.

Sebetulnya ada banyak pendidikan untuk perdamaian yang diterapkan di berbagai tempat di dunia, baik secara formal maupun informal, untuk anak-anak maupun orang dewasa. Ada yang memberi nama Perdamaian Internasional, Penelitian Konflik dan Manajemen Pemecahan Masalah, Pemecahan Perselisihan, Perdamaian dan Keadilan, dan masih banyak lagi yang jumlahnya lebih dari dua ratus. Apapun namanya, yang terpenting adalah isi dan metodenya untuk dikembangkan sebagai jalan keluar atas masalah yang ada dan untuk tndakan pencegahannya.

Keberhasilan pendidikan untuk perdamaian selain dua faktor di atas juga tergantung pada faktor lain, seperti: Guru. Guru dan pemimpin lainnya harus belajar dan meningkatkan kemampuan dan kesadaran bersama tentang masalah-masalah rasial, keagamaan, gender, wilayah, masyarakat, dan diskriminasi etnis yang terjadi dalam masyarakat. 


\section{Alternatif Ketiga}

Pendidikan perdamaian, menurut saya, dapat diberikan melalui kelompok-kelompok kegiatan ekstrakurikuler. Biasanya di sekolah-sekolah (lazimnya di sekolah lanjutan) memiliki beberapa kegiatan ekstrakuriluer seperti olahraga, drama, kesenian, kelompok ilmiah, dsb. Dengan format dan materi disesuaikan menurut macam kegiatan ekskul tersebut. Dalam kelompok ekskul olah raga dapat digunakan untuk mengembangkan sikapsikap seperti kejujuran, pengendalian emosi, persahabatan, menghormati orang lain, dsb. Untuk drama, misalnya dengan menciptakan drama yang mengangkat cerita untuk mengangkat sikap-sikap anti kekerasan, anti peperangan, menjunjung tinggi hak-hak asasi manusia, dab. Drama lebih fleksibel dan mudah untuk menanamkan sikap-sikap pro-perdamaian. Kegiatan lain, saya kira memiliki cara yang sesuai menurut bidang ketrampilannya masing-masing. Untuk kelompok - kelompok ketrampilan ini tentunya bisa diberikan tidak hanya kelompok ekskul pada lembaga pendidikan formal, tetapi club-club pendidikan informasi.

\section{G. Alternatif Pendidikan Perdamaian yang Paling Visible.}

Semua bentuk cara penyampaian pendidikan perdamaian di sekolah, menurut saya memiliki kelebihan dan kekurangan masing-masing. Saya kira, Lebih tepat jika pendidikan tentang perdamaian diberikan sebagai mata pelajaran tersendiri di sekolah. Jika hanya dimasukkan ke dalam kurikulum mata pelajaran tertentu ada banyak kekurangan dalam hal pemberian porsi waktu dan materinya. Karena sifatnya hanya mendompleng, materi yang bertujuan mengembangkan sikap-sikap pro-perdamaian akan diberikan setelah materi mata pelajaran yang dimasukinya. Sehingga porsinya hanya sedikit. Jika sedikit, mana mungkin bisa mengena dan mendarahdaging. Yang pasti yang diprioritaskan adalah materi matapelajaran utamanya. Celakanya lagi, jika guru lupa memasukkan materi yang berkaitan dengan pendidikan perdamaian.

Konsekuensinya jika diberikan sebagai matapelajaran tersendiri maka guru yang bersangkutan harus bisa, paling tidak, mengkaitkan dengan mata pelajaran yang lain. Relevansinya dengan IPS (sejarah, geografi, Sosiologi, Anthropologi jika di sekolah lanjutan atas), dengan matapelajaran IPS, pendidikan agama, dan lainnya, seperti apa dan bagaimana. Guru harus pandai mencari link materi pendidikan perdamaian dengan matapelajaran yang lain. 
Saya kira wajar karena dalam konteks kehidupan manusia menyangkut berbagai dimensi yang saling terkait dan ber-ketergantungan.

Saya kira yang paling penting adalah guru datang ke kelas dengan hati yang yang tulus untuk berbagi kasih sayang. Mengajar tanpa hati, maka murid pun belajar tanpa hati. Penanaman sikap-sikap dan ketrampilan di atas kepada para peserta didik juga harus dibekali dengan nilai-nilai spiritual. Pendidikan tidak hanya sekedar membuat kurikulum, namun, lebih dari itu yang utama adalah membangun sipiritualnya. Itulah yang harus menempel dan dikembangkan dalam peserta didik.

Pendidikan spiritualitas berkaitan dengan penghayatan seseorang terhadap suatu pengalaman hidup, pemahaman tentang srti hidup, bagaimana menjalani kehidupan, dan arti Tuhan dalam hidupnya. Penghayatan ini berkembang dari mulai anak, remaja, sampai orang dewasa. Sesuai dengan tingkat perkembangannya. (Welwood, 1993: seperti yang dikutip oleh Gamayanti, IL, 2008) Jika spiritual seseorang bagus, maka orang tersebut akan selalu berbuat baik dan melakukan yang terbaik untuk keluarga, sekolah/masyarakat, negara, dan agama. Berbuat baik ini salah satunya tidak berbuat yang merugikan orang lain dan diri sendiri.

\section{H. Kesimpulan}

Untuk menciptakan sebuah kehidupan masyarakat yang rukun dan damai tidak bisa hanya dalam sekejap mata. Betapa pun perlu waktu yang relatif cukup lama perdamaian harus tetap diciptakan. Usaha turut menciptakan perdamaian dapat dilakukan melalui jalur pendidikan baik formal maupun informal. Mengapa? Konflik dan berbagai macam tindakan kekerasan bersumber pada manusia. Artinya manusia adalah pelaku segala macam konflik dan tindakan kekerasan tadi. Karenanya usaha menciptakan perdamaian juga harus datang dan dilakukan oleh manusia. Karena perang bersumber dari pikiran manusia, maka usaha menghentikannya harus berawal dari manusia juga.

Sekolah baik tingkat dasar maupun lanjutan adalah sarana bagi anakanak (manusia) untuk mengembangkan pengetahuan, ketrampilan, dan sikapsikap yang telah diperoleh dari keluarga. Pendidikan perdamaian pun juga harus diterapkan pada kurikulum semua jenjang sekolah tadi. Karena pendidikan adalah proses yang terus menerus sampai akhir hayat. Sehingga usaha untuk mengenalkan dan mengembangkan sikap-sikap pro-perdamaian 
harus diberikan mulai dari sekolah dasar dan seterusnya. Tentu saja materi disesuaikan dengan tingkat pemahaman anak pada jenjang pendidikannya. Artinya sekolah bisa berperan menciptakan , menjaga, dan membangun perdamaian. Langkah yang bisa dilaksanakan adalah dengan memberikan materi tentang perdamaian di sekolah atau dalam kurikulum sekolah.

Materi pendidikan perdamaian dapat diberikan melalui beberapa cara. Tetapi menurut penulis, akan lebih efektif jika diberikan sebagai mata pelajaran yang berdiri sendiri. Kurikulumnya memuat materi yang mengintegrasikan dan mengkaitkan dengan mata pelajaran lain yang diajarkan di sekolah-sekolah. Melihat perkembangan yang terjadi di masyarakat lokal, nasional, regional, dan internasional, pendidikan perdamaian bukan lagi suatu hal yang diimplisitkan, sebagai hidden curriculum. Sudah saatnya anak-anak dari tingkat dasar ditanamkan sikap-sikap yang diperlukan untuk mencegah konflik dan kekerasan.

Pendidikan Perdamaian ataupun dengan menggunakan nama-nama lain pada dasarnya dalam rangka memberikan bekal pengetahuan, keterampilan, dan sikap agar mampu membina hubungan baik dalam setiap level interaksi manusia, dari anak-anak sampai orangtua, dari tingkat sekolah dasar sampai jenjang pendidikan tinggi. Selain itu, pendidikan perdamaian bertujuan untuk menciptakan dunia yang penuh dengan keadilan, tanpa kekerasan, saling menjunjung tinggi hak asasi manusia, tanpa konflik, tanpa eksploitasi satu sama lain, dan membina kehidupan yang penuh damai. Semua pihak harus optimis bahwa melalui sekolah bisa ditanamkan sikap-sikap yang perlu dikembangkan menuju kehidupan yang penuh damai. Nah, tinggal masalah tentang: Bagaimana pemerintah mendukung langkah pendidikan perdamaian ini? Misalnya di dalam kurikulum tingkat sekolah diwajibkan memuat tentang pendidikan perdamaian atau apa pun nama yang akan diberikan. Bagaimana guru yang mengajarkan perdamaian membekali murid-muridnya untuk mencegah dan mengakhiri segalam macam tindak kekerasan? Dan ketrampilan apa saja yang harus dimiliki guru pendidikan perdamaian untuk mengajarkan kepada murid-muridnya agar menjadi pendamai?

Sekolah sebagai wadah murid memperluas sikap, ketrampilan, dan pengetahuan, dapat berperan dalam menciptakan kehidupan yang rukun dan damai. Peran ini bisa diwujudkan dengan memberikan pendidikan perdamaian, atau apapun namanya, tetapi substansinya sama yaitu menanamkan kepada 
peserta didik sikap-sikap yang penting untuk mencegah terjadinya kekerasan yang saat ini marak di kalangan pelajar. Selain sikap juga ketrampilan dan kecerdasan spiritual. Untuk itu dibutuhkan kerjasama berbagai pihak.

Pemerintah seharusnya dapat membaca fenomena yang terjadi di kalangan pelajar, bahwa kecerdasan intelektual mereka tidak diimbangi dengan kecerdasan yang lain baik emosional dan spiritual. Jadi, tidak mengherankan jika banyak terjadi perkelahian antar pelajar atau konflik lainnya. Untuk dapat memahami maka seorang pemimpin negara (dalam hal ini presiden dan stafnya) seharusnya berasal dari kalangan terdidik dan berpendidikan tinggi, itu baru bisa memahami pentingnya dunia pendidikan. Pemerintah dapat memulainya dengan mewajibkan sekolah memberikan materi tentang perdamaian. Pada kurikulum standar di tiap jenjang pendidikan harus memuat materi tersebut.

Guru sebagai pemain dilapangan harus mampu memberikan kontribusi kepada para siswa untuk menjadi orang yang penuh cinta damai. Untuk tujuan tersebut, guru atau pendidikan lainnya harus cermat mengikuti isu-isu utama dalam mayarakat. Pandai mengajak siswa untuk menganalisis dan mendiskusikan cara mencegahnya dan mencari solusinya jika sudah terjadi. Sekolah beserta masyarakat sekolah diharapkan berperan aktif untuk turut mendukung tercapainya kehidupan yang rukun dan damai. Misalnya menciptakan budaya dialog antarwarga sekolah secara periodik. Tujuannya untuk menampung aspirasi ataupun guna memecahkan permasalahan yang ada. Budaya demokratis bisa dijadikan kultur sekolah. Siswa diharapkan setelah memperoleh pendidikan perdamaian, dapat mengaplikasikan ke dalam kehidupan bermasyarakatnya, baik di keluarga dan lingkungan sekitarnya (di sekolah, tempat kerja, tempat bermain, hidup bernegara dsb) serta di semua aspek kehidupan.

\section{DAFTAR PUSTAKA}

Baron, Stephen, Field, John, and Sculler, Tom. 2000. Social Capital: Critical Perspectives. New York: Oxford University Press Inc.

Furlong, Gary, T. 2005. The Conflict Resolution Toolbox: Models \& Maps for Analyzing, Diagnosing, and Resolving Conflict. Ontario: John Wiley \& Sons Canada, Ltd. 
Gamayanti, Indria Laksmi. 2008. Pendidikan IPS Sebagai Pembentukan Sikap dan Perilaku: Makalah dalam Seminar; "Membangun Spiritualisme Dalam Pendidikan IPS”. 9-10 Mei 2008. Yogyakarta.

Saidiharjo, Prof. 2004. Pengembangan Kurikulum Ilmu Pengetahuan Sosial. Yogyakarta.

Zamroni. 2008. Peace Education, Volume I, II, dan III. 